\title{
Potential control of bacterial epibiosis on the surface of the sponge Mycale adhaerens
}

\author{
On On Lee, Pei-Yuan Qian* \\ Department of Biology/Coastal Marine Laboratory, The Hong Kong University of Science and Technology, Clear Water Bay, \\ Kowloon, Hong Kong SAR
}

\begin{abstract}
Terminal restriction fragment length polymorphism (T-RFLP) analysis revealed structural differences in bacterial communities colonizing the surface of the sponge Mycale adhaerens or an inanimate reference surface. Since these surfaces are exposed to a common pool of indigenous bacterial colonizers in the water column, the differences in bacterial community structure were attributed to differences in chemical and/or physical characteristics between sponge and reference surfaces. In order to investigate a potential chemical interaction between sponge and bacterial communities, the effect of organic extracts from both the sponge and 20 bacterial isolates from the sponge surface was tested at tissue-level concentration on 36 bacterial isolates from the reference surface. Half of these isolates were susceptible to extract from sponge tissue and $61 \%$ to those of the isolates from the sponge surface; $30 \%$ were sensitive to extracts from both sponge and isolates. In contrast, only 1 of the isolates from the sponge surface was slightly inhibited by the sponge extract (5\%) and none by the extracts from the epibiotic isolates, supporting speculations on potential endo- and exogenous chemical control of bacterial epibiosis by the sponge and epibiotic bacteria, respectively.
\end{abstract}

KEY WORDS: Sponge $\cdot$ Mycale adhaerens $\cdot$ Bacterial epibiosis $\cdot$ Epibiotic bacteria $\cdot$ Benthic bacteria $\cdot$ Antibacterial activity $\cdot$ T-RFLP

Resale or republication not permitted without written consent of the publisher

\section{INTRODUCTION}

In the marine environment, all submerged surfaces are constantly exposed to and colonized by living organisms ranging from bacteria to macro-invertebrates. If this colonization occurs on animate surfaces, the phenomenon is referred to as epibiosis. The terms 'epibiont' and 'basibiont' describe the ecological roles of organisms in this association. While the former refers to organisms growing attached to a living surface, the latter refers to organisms serving as substrata for attachment by the epibionts (Wahl 1989).

Owing to their exceptionally high abundance in seawater, bacteria are often the pioneers and most abundant colonizers of exposed surfaces. Bacterial colonization can be beneficial or harmful. Macroalgae, for instance, benefit from nitrogen supplied by nitrogenfixing bacteria (Thevanathan et al. 2000). Also, bacterial colonization can slow down desiccation in some intertidal organisms during low tides (Penhale \& Smith
1977) and induce macroalgal morphogensis in Ulva sp. (Nakanishi et al. 1999). However, in many cases, the harmful effects of bacterial epibiosis can outweigh the beneficial ones. For example, bacterial epibionts can induce disease and tissue necrosis (Mitchell \& Chet 1975), obstruct feeding, gaseous exchange and waste excretion in basibionts, and can compete with basibionts for resources (Witman \& Suchanek 1984, Davis et al. 1989, Wahl 1989, Lesser et al. 1992). Basibionts may also suffer from damage due to grazers feeding on bacterial epibionts (Bronmark 1985). Since bacteria are important sources of chemical cues for larval settlement of many benthic invertebrates (Wieczorek \& Todd 1998, Lau et al. 2002), bacterial epibiosis may further affect basibionts by promoting invertebrate colonization (Dixon et al. 1981, Wahl 1997).

In order to minimize negative impacts, basibionts have to develop mechanisms to control bacterial colonization. Many bioactive substances with potent antibacterial activities have been discovered from benthic 
marine invertebrates such as gorgonians (Targett et al. 1983, Bandurraga \& Fenical 1985, Jensen et al. 1996), ascidians (Wahl et al. 1994), soft corals (Slattery et al. 1995, Kelman et al. 1998, Harder et al. 2003), and sponges (Burkholder \& Ruetzler 1969, McCaffrey \& Endean 1985, Amade et al. 1987). Therefore, it is generally believed that bacterial epibiosis can be controlled endogenously by the metabolites of basibionts (Bakus et al. 1986, Davis et al. 1989, Paul 1992). Bacterial epibiosis can also be controlled mechanically by sloughing of epithelial tissue (Barthel \& Wolfrath 1989), and maintaining surface tension (Becker \& Wahl 1991), wettability (Dexter et al. 1975) and pH (Baker \& Orr 1986), which are unfavorable for bacterial colonization. Besides, there is increasing evidence that certain epibiotic bacteria can inhibit the growth and attachment of other bacteria competing for the same niche (Holmström et al. 1996, Boyd et al. 1999b, Thakur \& Anil 2000). Therefore, it is possible that basibionts can acquire an exogenous biological defense by maintaining a synergistic relationship with specific bacteria that have inhibitory effects on the growth and attachment of potentially harmful bacteria.

In a previous study, we showed that the sponge Mycale adhaerens exhibited a chemical defense against colonization by benthic invertebrate larvae and a possible control of bacterial epibiosis was proposed (Lee \& Qian 2003). To investigate a potential control of bacterial epibiosis in $M$. adhaerens, the first objective of the present study was to compare the bacterial community on the surface of $M$. adhaerens with that of an inanimate reference surface by using terminal restriction fragment length polymorphism (T-RFLP) analysis of bacterial community DNA. Since the 2 surfaces were exposed to the same pool of bacterial colonizers, any difference in the bacterial community profile was hypothesized to stem from sponge-related attributes. The possible existence of an endogenous chemical control of bacterial epibiosis in $M$. adhaerens was investigated by testing the organic extract of sponge tissue against bacteria isolated from the reference and the sponge surfaces. Finally, the possibility of an exogenous biological control was investigated by testing the organic extracts of epibiotic bacteria isolated from the sponge against the bacteria from the reference and the sponge surfaces.

\section{MATERIALS AND METHODS}

DNA fingerprinting analysis of bacterial communities. For the analysis of bacterial communities by terminal restriction fragment length polymorphism (TRFLP) analysis of 16S rRNA genes (rDNA), colonies of Mycale adhaerens grown on polystyrene plates $(\mathrm{n}=4$, each with a surface area of ca. $40 \mathrm{~cm}^{2}$ ) were collected at a fish farm in Long Harbour, Hong Kong, rinsed with autoclaved $0.22 \mu \mathrm{m}$ FSW (AFSW), and swabbed with sterile cotton tips to remove the existing epibiotic bacterial community. The sponges were put back into the sea for $7 \mathrm{~d}$ to allow the development of a new bacterial community. During this period of time, sterile polystyrene dishes ( $\mathrm{n}=4$, each with a surface area of ca. 40 $\mathrm{cm}^{2}$ ) were submerged at the same site for the development of a reference bacterial community.

After $7 \mathrm{~d}$, the sponges and polystyrene dishes were retrieved and rinsed with AFSW. Bacterial communities on the surfaces ( $\mathrm{n}=4$ for each, with acronyms S1S4 for the sponge surface and N1-N4 for the reference surface) were collected by swabbing with sterile cotton tips and immediately frozen in $0.8 \mathrm{ml}$ of extraction buffer (100 mM Tris-HCl, $100 \mathrm{mM} \mathrm{Na}_{2}$-EDTA, $100 \mathrm{mM}$ $\mathrm{Na}_{2} \mathrm{HPO}_{4}, 1.5 \mathrm{M} \mathrm{NaCl}, 1 \% \mathrm{CTAB} ; \mathrm{pH}$ 8) and transferred to the laboratory. Bacterial cells were lysed in 2 freeze-thaw cycles using liquid nitrogen and a $60^{\circ} \mathrm{C}$ water bath. The extraction and purification of total DNA followed the SDS-based method described in Liu et al. (1997).

The 16S rDNA of bacteria were amplified by PCR using primers 341F (5'-CCTACGGGAGGCAGCAG3') and 926R-Fam (5'-CCGTCAATTCCTTTRAGTTT3') (Liu et al. 1997). The latter was labeled with 6-carboxy fluorescein (FAM) at the $5^{\prime}$ end. PCR conditions were 5 min initial denaturation at $94^{\circ} \mathrm{C}_{i}$ followed by 30 cycles of denaturation $\left(94^{\circ} \mathrm{C}, 1 \mathrm{~min}\right)$, annealing $\left(55^{\circ} \mathrm{C}\right.$, $1 \mathrm{~min})$ and extension $\left(72^{\circ} \mathrm{C}, 2 \mathrm{~min}\right)$; and final extension at $72^{\circ} \mathrm{C}$ for $5 \mathrm{~min}$. PCR products were cleaved with $10 \mathrm{U}$ of the restriction enzyme $M s p I$ at $37^{\circ} \mathrm{C}$ for $6 \mathrm{~h}$, followed by purification with the Wizard ${ }^{\circledR}$ PCR preps DNA purification system (Promega) according to the manufacturer's protocol. Ten $\mu$ l of purified products together with $0.5 \mu \mathrm{l}$ internal size standard (ET-550R, Amersham) were denatured $\left(95^{\circ} \mathrm{C}\right.$ for $\left.2 \mathrm{~min}\right)$, snap cooled on ice, and analyzed by electrophoresis on a MegaBACE genetic analyzer (Amersham) operated in the genotyping mode. After electrophoresis, the size of the fluorescently labeled terminal restriction fragments was determined by comparison with internal standards, using the software Fragment Profiler (Amersham). Terminal restriction fragments (T-RFs) of less that 50 fluorescence units in intensity, and of $<35$ and $>550$ bp in size were excluded from the analysis to avoid uncertainties in size determination.

The electropherograms were analyzed by visual comparison of T-RFLP patterns and by cluster analysis. Agglomerative hierarchical clustering was performed using the similarity matrix determined by Ward's method and was displayed as dendrograms using the software STATISTICA (Clarke \& Warwick 1994). 
Isolation and characterization of bacteria. Epibiotic bacteria from the sponge surface were collected by swabbing the surface of 6 sponge colonies (each with a surface area of ca. $40 \mathrm{~cm}^{2}$ ) with sterile cotton tips, which were then suspended in AFSW in 6 different culture tubes. Omnipresent bacterial colonizers were collected analogously from 6 sterile polystyrene petri dishes (ca. $40 \mathrm{~cm}^{2}$ of surface area) that had been submerged for $7 \mathrm{~d}$ at the same site as the sponges.

The bacterial suspensions were diluted 10- or 100fold with AFSW; $200 \mu$ liquots of each dilution were spread on nutrient agar $(0.5 \%$ peptone, $0.3 \%$ yeast extract, $1.5 \%$ agar in AFSW) and incubated at $28^{\circ} \mathrm{C}$ under a 15:9 h light:dark photoperiod for $24 \mathrm{~h}$. Morphologically distinct colonies were isolated, purified and preserved in $50 \%$ glycerol at $-80^{\circ} \mathrm{C}$.

Bacterial isolates were characterized by comparative sequence analysis of $16 \mathrm{~S}$ rDNA fragments. Bacterial DNA was extracted according to Valsecchi (1998), and 16S rDNA fragments amplified by PCR using primers 355F (5'-CACGAGCTGACGACAGCCAT-3') and 1055R (5'-ACTCCTACGGGAGGCAGC-3') (Amann et al. 1990, Lee et al. 1993) as described above. Cycle sequencing of PCR amplicons were performed bidirectionally using the same primer set and the BigDyelabeled terminator reaction mix (Applied Biosystems) according to the manufacturer's protocol. The products were purified with Centri-Sep Spin Columns (Princeton Separations) and sequences were analyzed on an ABI PRISM ${ }^{\mathrm{TM}} 310$ genetic analyzer (Applied Biosystems). The nucleotide sequences were compared against those at GenBank using BLAST (Basic Local Alignment Search Tool) on the NCBI (National Center for Biotechnology Information) server. Phylograms were constructed by using the neighbor-joining algorithm (Saitou \& Nei 1987). The 16S rDNA sequences of isolates are available in the GenBank under the accession numbers AY241396-AY241455.

Production of organic extracts from sponge tissue and bacterial isolates. For the production of organic extracts from sponge material, colonies were brought to the surface, rinsed with AFSW to remove waterborne bacteria and the tissue volume was measured by water displacement. Approximately $100 \mathrm{ml}$ of sponge colonies were blot-dried, cut into small pieces and transported to the laboratory in $200 \mathrm{ml}$ of a $1: 1$ mixture of methanol/chloroform. After $24 \mathrm{~h}$, sponge tissue was removed from the solvent and the volume of the extract was reduced to $100 \mathrm{ml}$ by evaporation in vacuo. This volume was equivalent to the volume of sponge tissue being extracted, and the extract thus regarded as being at the 'tissue-level concentration' (TLC), a measure frequently used to describe a presumptive homogenous distribution of extractable compounds in the tissue of soft-bodied organisms (Slattery et al. 1995, Jensen et al. 1996).

For the production of organic extracts from epibiotic bacteria, isolates were grown in nutrient broth $(0.5 \%$ peptone, $0.3 \%$ yeast extract in AFSW) to the stationary phase, and harvested and washed by centrifugation at $6000 \times g$ for $15 \mathrm{~min}$. Bacterial pellets were suspended in a 1:1 mixture of methanol/chloroform (approx. $1 \mathrm{~g}$ of pellet in $10 \mathrm{ml}$ methanol/chloroform). After $12 \mathrm{~h}$ of extraction at room temperature $\left(\sim 24^{\circ} \mathrm{C}\right)$ with agitation $(120 \mathrm{rpm})$, the organic extracts were separated from cell debris by centrifugation at $6000 \times g$ for $15 \mathrm{~min}$.

Disc-diffusion assays. Antibacterial activities of sponge tissue extracts and those of the epibiotic bacteria were tested by disc-diffusion assays following the procedures in Harder et al. (2003). Isolates from the sponge and the reference surfaces were grown to the stationary phase in nutrient broth. Two hundred $\mu \mathrm{l}$ of these cultures were spread on nutrient agar. Sterile paper discs (6.5 mm diameter, Whatman, No. 1) each loaded with $20 \mu$ l of extracts (equivalent to the volume of a paper disc) from sponge or epibiotic bacterial isolates were subsequently placed on the inoculated agar. Pure solvents (20 $\mu$ l of methanol/ chloroform per disc) and streptomycin (50 $\mu \mathrm{g}$ per disc) served as controls. After $24 \mathrm{~h}$ of incubation at $28^{\circ} \mathrm{C}$, the bacteria developed confluent lawns and the width of growth inhibition zone around each paper disc was measured.

\section{RESULTS}

\section{T-RFLP analysis of bacterial communities}

Bacterial communities from sponge and reference surfaces displayed distinctive T-RFs (Fig. 1). T-RFs of $121,150,248$ and 310 bp were found only in the sponge samples while T-RFs of 127,315 and $366 \mathrm{bp}$ were found only in the reference samples. Cluster analysis of T-RF patterns indicated that the bacterial communities obtained from the sponge surface were distant from those of the reference surfaces (linkage distance $=10$; Fig. 2). For both sponge and reference samples, bacterial communities among replicates were highly similar (linkage distance <5; Fig. 2).

\section{Isolation and characterization of bacteria}

A total of 36 morphologically distinct bacteria were isolated from the reference surface. Comparative sequence analysis of $16 \mathrm{~S}$ rDNA fragments revealed that 24 bacteria belonged to the $\gamma$-subdivision of Proteobacteria (Fig. 3), 2 to the $\alpha$-subdivision of Pro- 


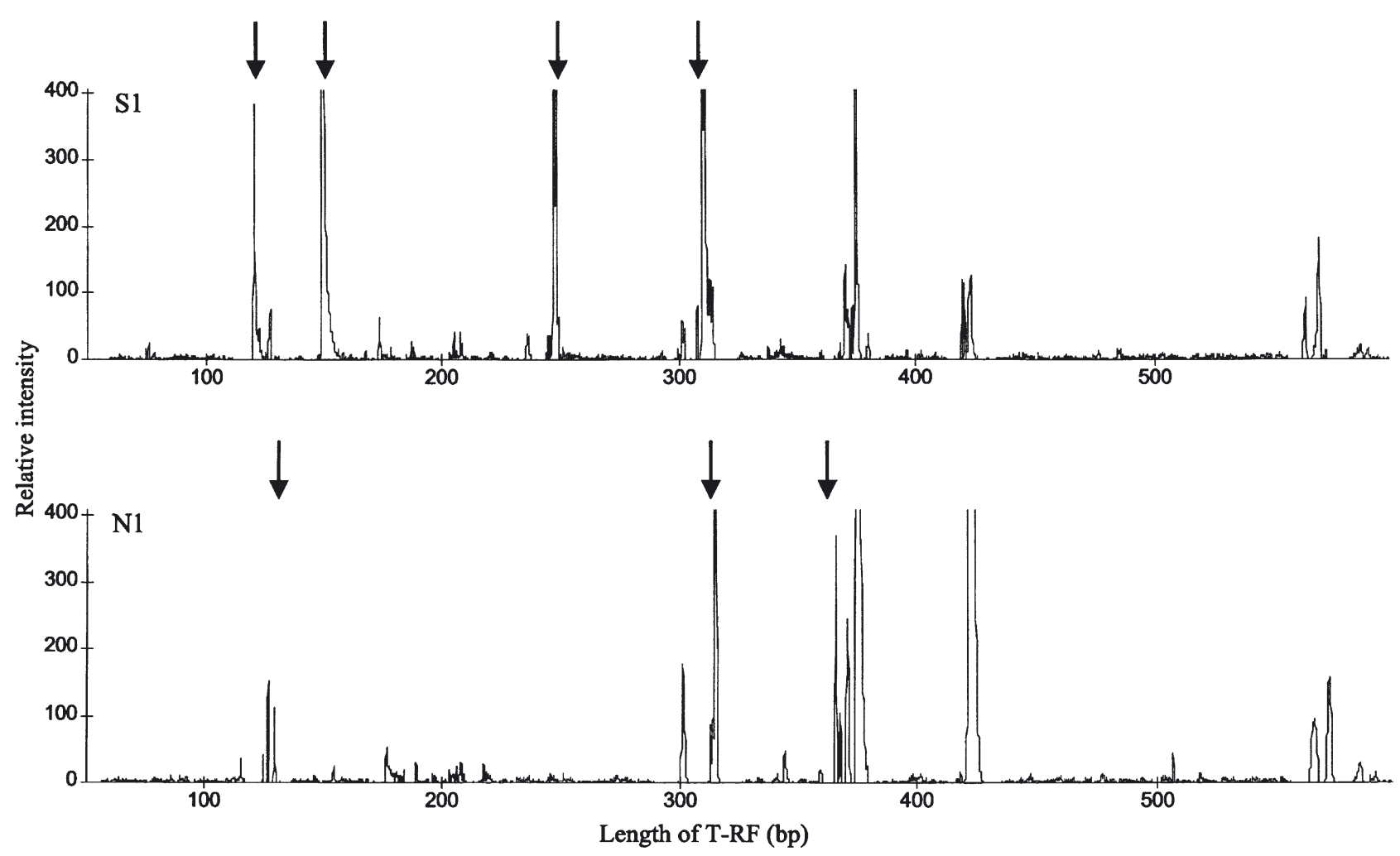

Fig. 1. Representative electropherograms of T-RFs derived from MspI digestion of PCR-amplified bacterial community DNA obtained from the sponge surface (S1) and reference surface (N1). Distinctive T-RFs are indicated by arrows

teobacteria (Fig. 4), 8 to the division of Gram-positive bacteria (Fig. 5), and 2 to the Cytophaga-FlexibacterBacteriodetes division (Fig. 6). From the sponge surface, 20 morphologically bacteria were obtained. Of these, 11 belonged to the $\gamma$-subdivision of Proteobacteria (Fig. 3), 3 to the $\alpha$-subdivision of Proteobacteria (Fig. 4), 5 to the division of Gram-positive bacteria (Fig. 5), and 1 to the Cytophaga-FlexibacterBacteriodetes division (Fig. 6).

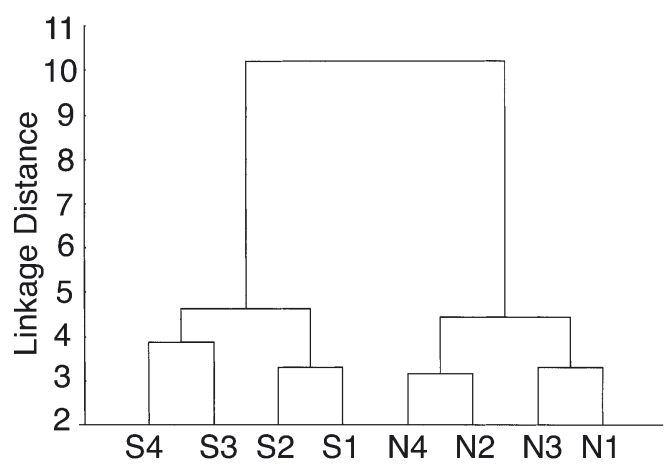

Fig. 2. Dendrogram showing the relatedness of bacterial communities on the sponge (S1-S4) and reference surfaces (N1-N4)

\section{Antibacterial activity of organic extracts}

All bacteria isolates, except 4 (N30 and N48; S3 and S4), were susceptible to streptomycin, with growth inhibition zones ranging from 0.3 to $11.5 \mathrm{~mm}$ (Figs. 7 $\&$ 8). The solvent controls showed no effect (data not shown). Out of 36 bacterial isolates from the reference surface, covering 3 phylogenetic branches $(\gamma$-subdivision of Proteobacterium, Gram-positive, and Cytophaga-Flexibacter-Bacteriodetes), 18 were susceptible to sponge extract at TLC, with growth inhibition zones ranging from 0.2 to $6.3 \mathrm{~mm}$ (Fig. 7). For most of the susceptible bacteria (e.g. N32 and N39), growth inhibition was indicated by clear zones around experimental paper discs. For 5 bacteria that belonged to Vibrio (N11, N31 and N40) and Pseudoalteromonas (N2 and N43); however, growth inhibition was indicated by halos clearly distinguishable from the unaffected bacterial lawn by reduced opacity (Fig. 7), indicating a weak inhibition of bacterial growth. In contrast, only 1 isolate out of 20 from the sponge surface was susceptible to the sponge extract, showing a growth inhibition zone of $1.9 \mathrm{~mm}$ (Fig. 8).

Organic extracts of the isolates from the sponge surface inhibited growth of 22 isolates from the reference 


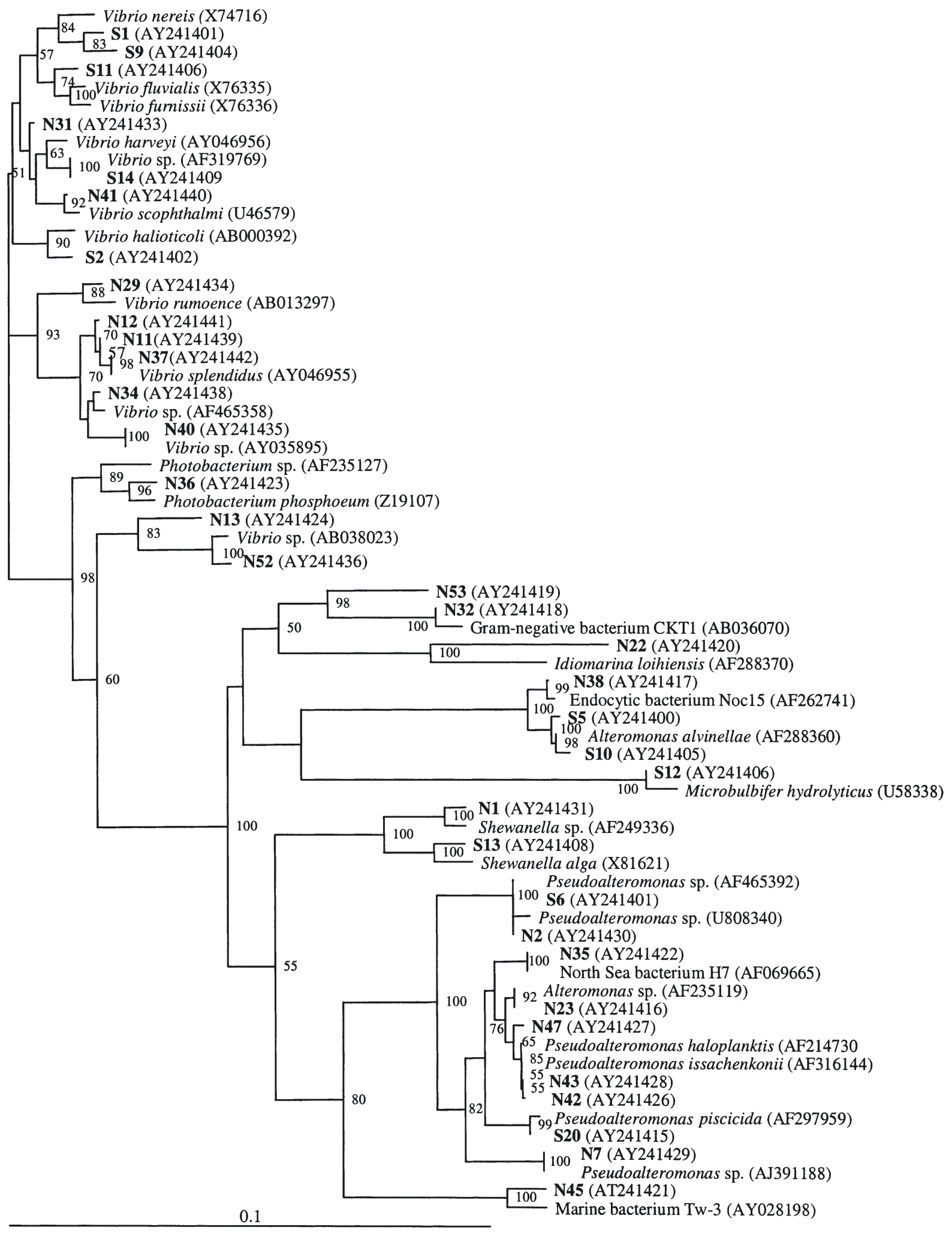

Fig. 3. Neighbor-joining tree showing genetic distances between bacterial isolates from the sponge surface (S) or the reference surface $(\mathrm{N})$ in reference to members of the $\gamma$-subdivision of Proteobacteria. Nucleotide accession numbers are given in parentheses. Scale bar represents 0.1 substitutions per nucleotide position. Bootstrap values based on 1000 resampling are indicated by the numbers at the nodes 


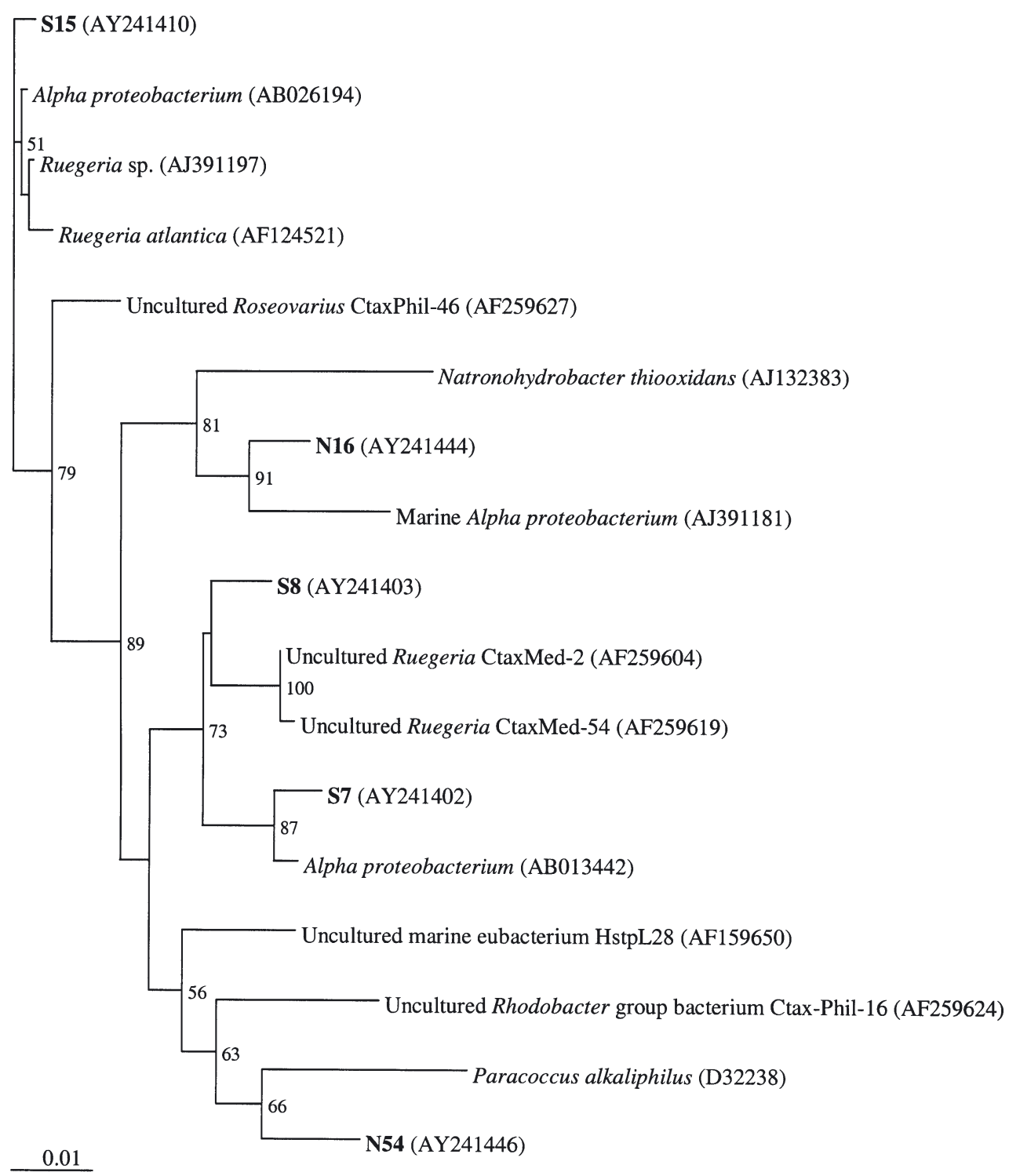

Fig. 4. Neighbor-joining tree showing genetic distances between bacterial isolates from the sponge surface (S) or the reference surface $(\mathrm{N})$ in reference to members of the $\alpha$-subdivision of Proteobacteria. Nucleotide accession numbers are given in parentheses. Scale bar represents 0.1 substitutions per nucleotide position. Bootstrap values based on 1000 resampling are indicated by the numbers at the nodes

surface, producing growth inhibition zones ranging from 0.8 to $13.1 \mathrm{~mm}$ (Table 1) but none of the epibiotic bacteria isolated from the sponge surface was susceptible to the bacterial extracts. Some inhibition zones were larger than those created by streptomycin (e.g. S9 vs N54; S11 vs N44). Highest potency was observed from S9, S11 and S16, which affected at least $41.7 \%$ of the isolates from the reference surface, with growth inhibition zones ranging from 0.6 to $13.1 \mathrm{~mm}$ (Table 1). Some isolates from the reference surface (e.g. N20, N44 and N54) were susceptible to extracts of at least 10 epibiotic bacteria (Table 1).

\section{DISCUSSION}

T-RFLP analysis of 16S rDNA revealed that bacterial communities developed on the sponge and reference surfaces over a $7 \mathrm{~d}$ submersion period were substantially different (Figs. $1 \& 2$ ). Distinctive T-RFs were present in each community such as the T-RF clusters at 150 and $248 \mathrm{bp}$ in the sponge samples, and at $366 \mathrm{bp}$ in the reference samples (Fig. 1). Since the 2 surfaces were in the same water column for the same time period and thus exposed to the same pool of bacterial colonizers, the observed differences in bacterial community profiles 


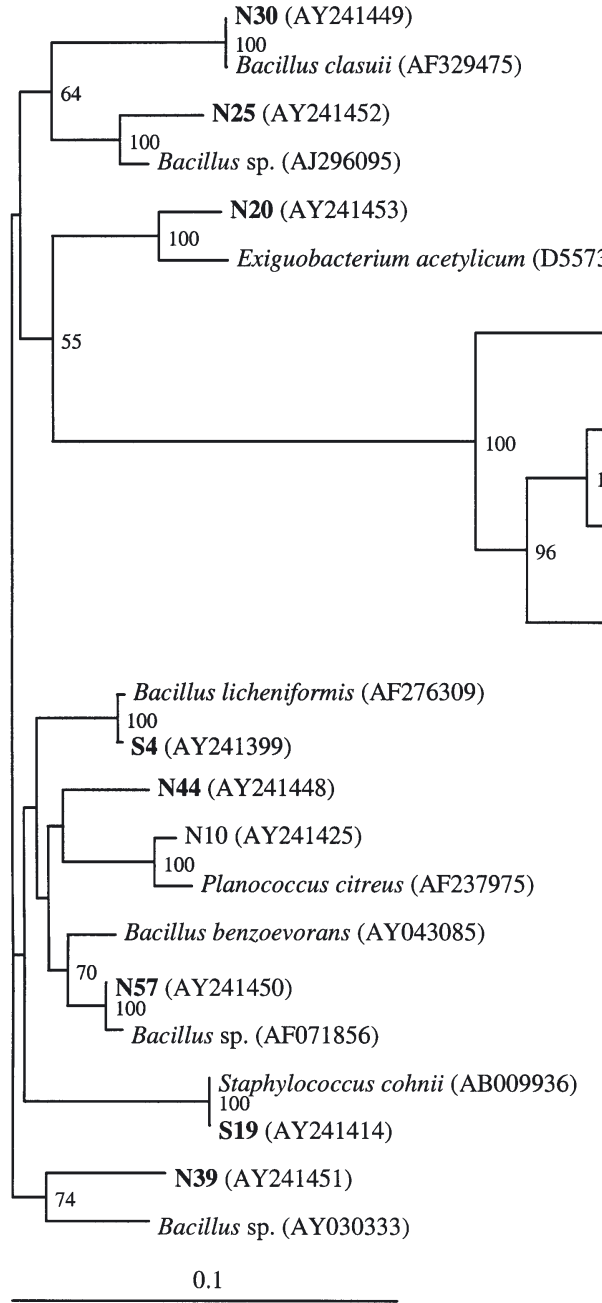

\& Endean 1985, Amade et al. 1987). In a more recent study, Kubanek et al. (2002) demonstrated that triterpene glycosides isolated from 2 Caribbean sponges, Ectyoplasia ferox and Erylus formosus, had a significant inhibition effect on the attachment of bacteria. In our study, we found that $50 \%$ of the benthic bacterial isolates were sensitive to the sponge extract. Therefore, the observed differences in bacterial community structures between the sponge and reference surfaces could be due to the direct inhibitive effects of sponge metabolites on the bacteria.

It should be pointed out that, although our results clearly indicated that the sponge extract inhibited the growth of ecologically relevant (i.e. benthic) bacteria at tissue level concentration, it is still unknown to what extent the active extract components were present at the sponge surface and were thereby encountered by bacterial colonizers. Likely due to selection by the nutrient-rich culture medium, many of the epibiotic and benthic might be attributed to (1) the influence of the sponge metabolites on attachment and growth of marine bacteria (see also Harder et al. 2003, Lee \& Qian 2003), (2) the influence of metabolites of early colonizing bacteria on the attachment and growth of other bacteria (Hentschel et al. 2001, Harder et al. 2003), or (3) the possible physical characteristic differences between the sponge and reference surfaces (Fletcher \& Marshall 1977).

Antibacterial activities in extracts or metabolites from sponges have been extensively studied for years (Burkholder \& Ruetzler 1969, McCaffrey \& Endean 1985, Amade et al. 1987, Kubanek et al. 2002). The extracts of the sponges Thorecta vasiforis, Arenochalina mirabilis and Acanthella kleutha, for instance, had similar inhibitive effects on a group of bacteria as antibiotic treatments (McCaffrey \& Endean 1985). Sponge extracts also had stronger inhibitive effects on Gram-positive bacteria (McCaffrey

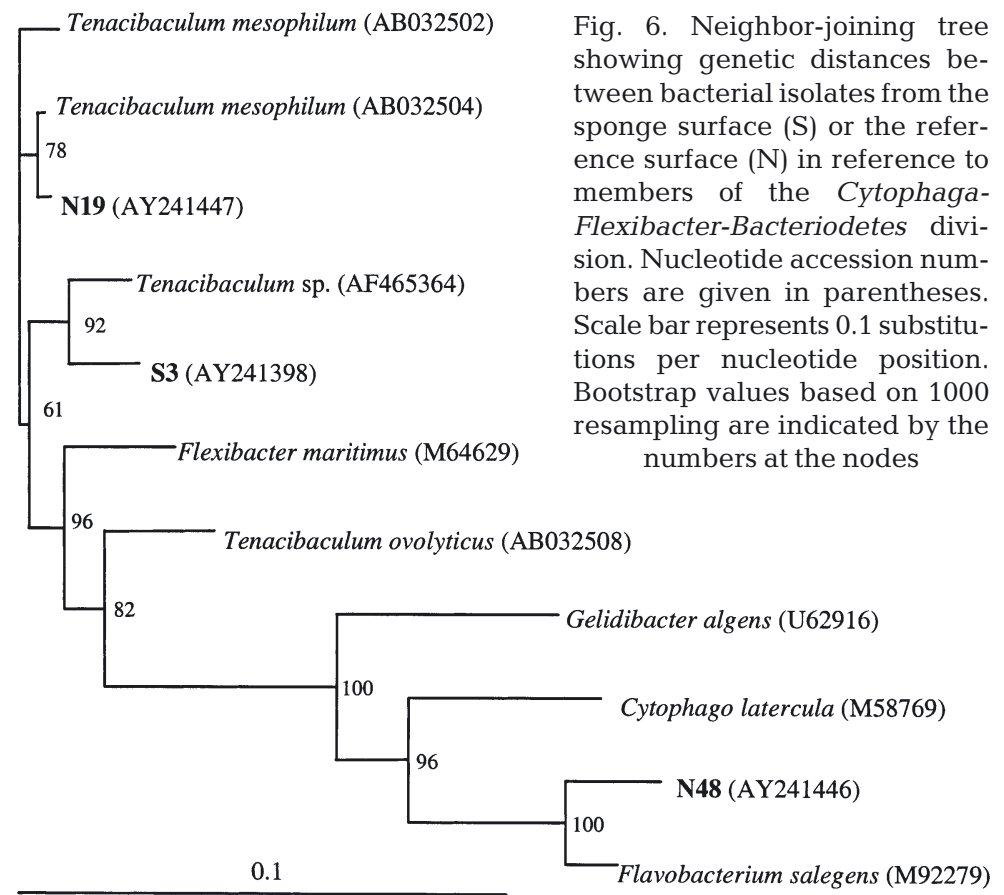




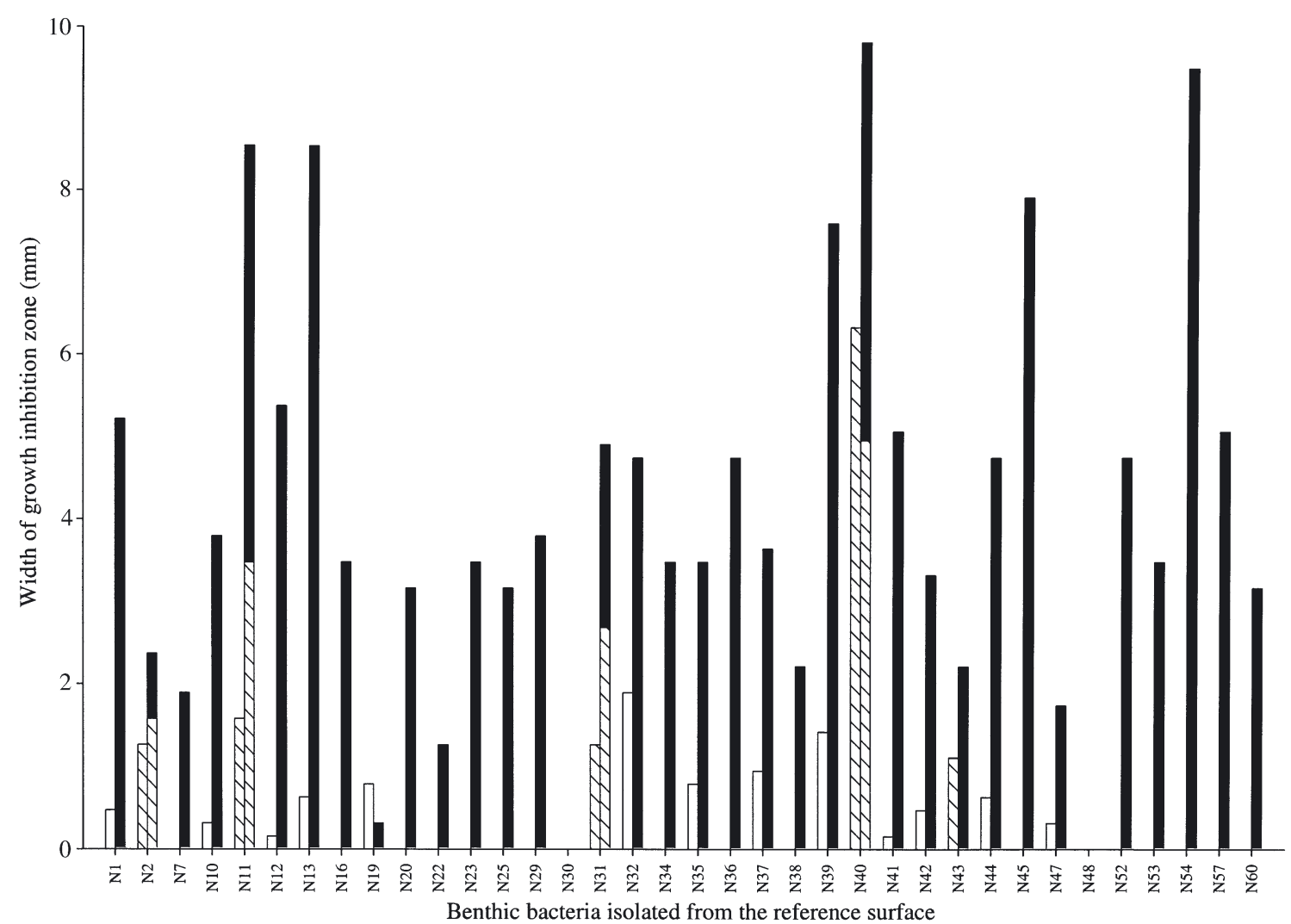

Fig. 7. Susceptibility of isolates from the reference surface to sponge tissue extract at tissue level concentration (TLC). Black areas represent inhibition zones induced by streptomycin and sponge extract, respectively. Striped areas indicate a halo within an inhibition zone

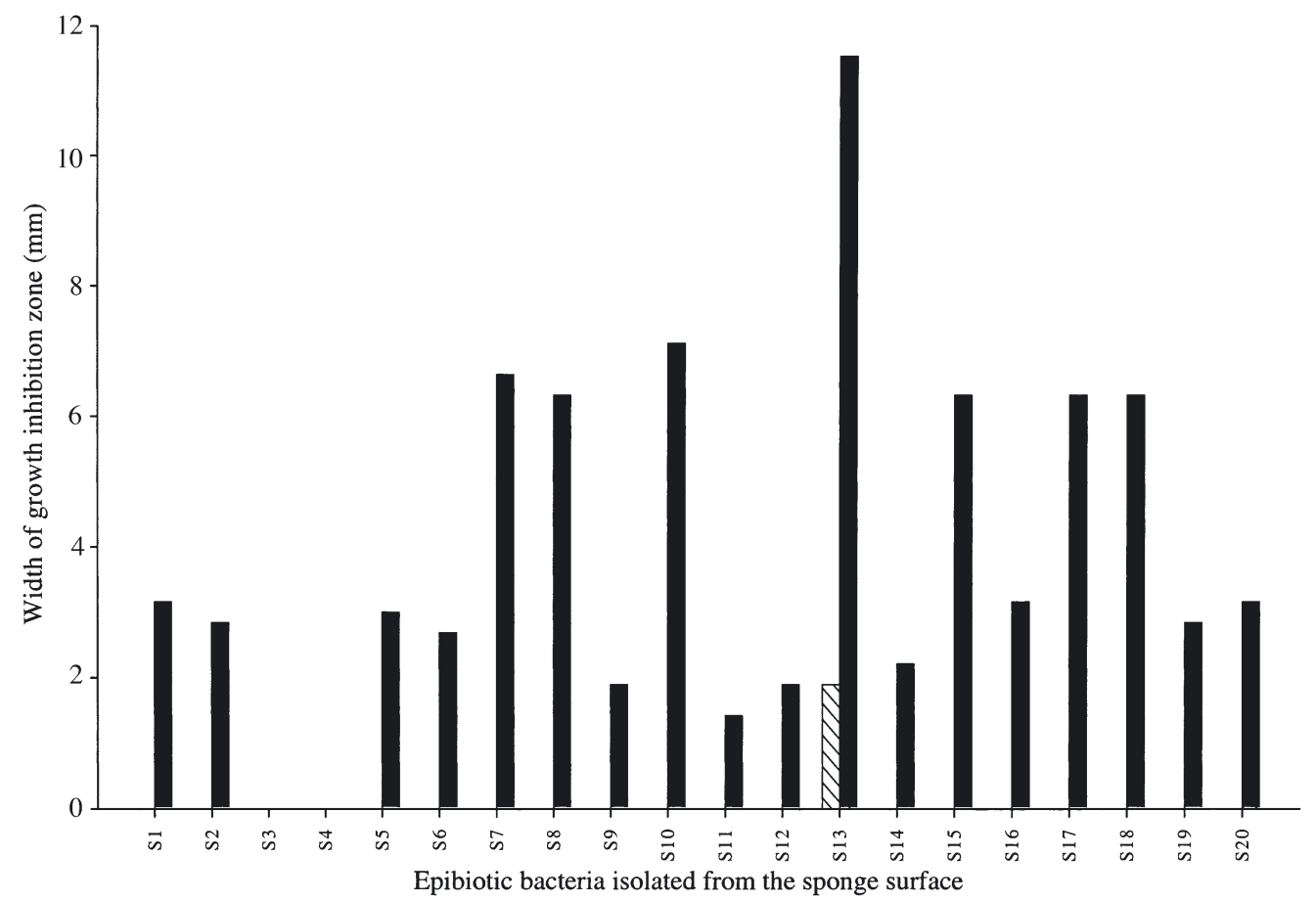

Fig. 8. Susceptibility of isolates from the sponge surface to sponge tissue extract at tissue level concentration (TLC). Black areas represent inhibition zones induced by streptomycin. Striped area indicates a halo induced by sponge extract 
bacteria were closely related (Figs. 3 to 6 ). For example, 13 benthic and 5 epibiotic bacteria belonged to Vibrio, and 9 benthic and 3 epibiotic bacteria belonged to Pseudoalteromonas (Fig. 3). However, the close phylogenetic relationship was not reflected in their response to the sponge extract since all epibiotic bacteria, except S13 (showing a halo), were resistant to the sponge extract (Fig. 8). Thus, the highly specific inhibitive effect of sponge extract on benthic bacteria could indicate a potential ecological role of the sponge extract components in the selection of epibionts and of basibiont defense.

On the other hand, some bacteria can inhibit the growth and attachment of other bacteria that are competing for the same niche. Their presence thereby constitutes an exogenous biological defense for the basibionts (Holmström et al. 1996, Boyd et al. 1999a, Thakur \& Anil 2000, Henstchel et al. 2001, Harder et al. 2003). For instance, water soluble products of the bacteria isolated from the surface of the soft coral Dendronephthya sp. have been reported to have anti-growth and antiattachment effects on indigenous benthic bacteria (Harder et al. 2003). Bacteria in the genera Pseudoalteromonas and the $\alpha$ Proteobacteria isolated from 2 Mediterranean sponges, Aplysina aerophoba and A. cavernicola, were more active in inhibiting bacterial growth than those in other genera (Hentschel et al. 2001). Surface-associated bacteria of the sponge Ircinia ramose were also capable of producing antibacterial metabolites that might help the sponge to control bacterial epibiosis (Thakur \& Anil 2000). In the present study, the exclusive inhibition of bacteria isolated from the reference surface by organic extracts from epibiotic bacteria suggested that the isolates from the 2 surfaces differed physiologically, although they could not be distinguished phylogenetically. The broad and potent inhibitive effect of extracts from the epibiotic bacteria against the isolates from the reference surface indicated that exogenous control of bacterial epibiosis in the sponge is highly possible, which might have led to the differences in bacterial community structure between the sponge and reference surfaces. 
Although the chemical defense is likely a process leading to the differences in bacterial community structures of the 2 surfaces, we cannot entirely rule out the potential influences of the differences in physical characteristics of those surfaces. Firstly, the Petri dish surfaces (i.e. the reference surfaces) were smoother than the rough surfaces of the sponge. It has been suggested that surface roughness can affect electrostatic interactions with bacteria due to their effect on repulsion forces (Fletcher \& Marshall 1977) and different types of surfaces can have different degrees of wettability and hydrophobicity, which can in turn affect the attachment of marine bacteria (Dexter et al. 1975). However, the relationship between the surface physical characteristics and bacterial attachment is far from being conclusive. For instance, Dexter et al. (1975) found that the number of bacteria attached to surfaces had a parabolic function to the critical surface tension for wetting with a minimum at around 25 dyn $\mathrm{cm}^{-1}$. Becker \& Wahl (1991) found that substrata with high hydrophobicity or with surface free energy between 31 and $43 \mathrm{mN} \mathrm{m}^{-1}$ were heavily colonized by bacteria and other microorganisms. However, Qian et al. (2000) found that bacteria did not attach well to substrate with either the largest contact angle (Teflon surface) or the smallest contact angle (glass surface) and there was no good correlation between bacterial density and contact angles of substrate. Since none of these studies has examined the composition of the microbial film, it is impossible to determine how individual bacterial species attach to the surface in response to different contact angles, surface free energy or wettability. Without a good understanding of the interaction of individual bacterial species with surface physical characteristics, it is rather difficult to determine how the bacterial community develops in response to physical characteristics. The physical attributes are certainly worthy of future investigation in order to gain a more comprehensive understanding on the control of bacterial epibiosis on this sponge.

In the present study, bacterial community DNA was obtained by swabbing the surface of a sponge with sterile cotton tips. We did this instead of extracting the whole sponge tissue because only the epibiotic bacterial community was targeted, not the internal one. We cannot ignore the fact that our sampling strategy might have selectively picked up those bacteria less firmly attached to the surfaces and not those firmly attached. However, this limitation would be applicable to both sponge and reference surfaces and, thus, should not influence our overall conclusion as to the differences between 2 bacterial communities. The differences in bacterial community structure between sponge and reference surfaces were also demonstrated by using the culture-dependent method, which showed that the culturable bacteria on the surface of this sponge had much lower diversity than those on the reference surface and less than $10 \%$ of bacterial isolates could be found on both surfaces (Lee \& Qian 2003). Therefore, we do not expect profound effects from our sampling strategy on bacterial community structure of those surfaces.

In conclusion, by means of T-RFLP analysis of bacterial DNA and anti-growth (i.e. disc-diffusion) assays, we provided evidence for the possible control of bacterial epibiosis in Mycale adhaerens. Our results suggested some highly specific interactions among $M$. adhaerens, its epibiotic bacteria and the benthic bacteria. These interactions may explain the observed differences in bacterial communities between the sponge and reference surfaces as due to a potential chemicalmediated control of bacteria epibiosis. It is reasonable to hypothesize that the sponge can produce antibacterial substances inhibiting the growth of benthic bacteria and therefore chemically control bacterial epibiosis. The general resistance of epibiotic bacteria to sponge tissue and reciprocally tested bacterial extracts suggested a potential symbiotic relationship between the sponge and epibiotic bacteria. Lastly, this relationship may help the sponge to control colonization by benthic bacteria since the antibacterial effect of epibiotic bacteria was 'niche-specific' (i.e. inhibit the growth of many benthic bacteria but not the epibiotic bacteria). Since both endo- and exogenous chemical controls of bacterial epibiosis are possible in this sponge, the inhibitive effects of organic extracts from both the sponge tissue and epibiotic bacteria on benthic bacteria will be further investigated in order to identify the composition or structure of bioactive substances.

Acknowledgements. The authors are grateful to S. C. K. Lau and T. Harder for productive discussions during the course of this work. Thanks are also due to L. Soo and Y. K. Tam for technical assistance, and Dr. V. Unkefer for proof-reading the manuscript. This study was supported by RGC grants (HKUST6119/01M，HKUST6100/02M，CA00/01. SC01) to P.Y.Q.

\section{LITERATURE CITED}

Amade P, Charroin C, Baby C, Bacelet J (1987) Antimicrobial activities of marine sponges from the Mediterranean Sea. Mar Biol 94:271-275

Amann RI, Krumholz L, Stahl DA (1990) Fluorescentoligonucleotide probing of whole cells for determinative, phylogenetic, and environmental studies in microbiology. J Bacteriol 1972:762-770

Baker JH, Orr DR (1986) Distribution of epiphytic bacteria on freshwater plants. J Ecol 74:155-165

Bakus GJ, Targett NM, Schulte B (1986) Chemical ecology of marine organisms: an overview. J Chem Ecol 12:951-987

Bandurraga MM, Fenical W (1985) Isolation of the muricins: evidence of a chemical adaptation against fouling in the marine octocoral Muricea fruticosa (Gorgonacea). Tetrahedron 41:1057-1065

Barthel D, Wolfrath B (1989) Tissue sloughing in the sponge Halichondria panicea: a fouling organism prevents being 
fouled. Oecologia 78:357-360

Becker D, Wahl M (1991) Influence of substratum surface tension on biofouling of artificial substrata in Kiel Bay (Western Baltic): in situ studies. Biofouling 4:275-291

Boyd KG, Adams DR, Burgess JD (1999a) Antibacterial and repellent activities of marine bacteria associated with algal surfaces. Biofouling 14:227-236

Boyd KG, Mearns-Spragg A, Burgess JG (1999b) Screening of marine bacteria for the production of microbial repellents using a spectrophotometric chemotaxis assay. Mar Biotechnol 1:359-363

Bronmark C (1985) Interactions between macrophytes, epiphytes and herbivores: an experimental approach. Oikos 45:26-30

Burkholder PR, Ruetzler K (1969) Antimicrobial activity of some marine sponges. Nature 222:983-984

Clark KR, Warwick RM (1994) Changes in marine community: an approach to statistical analysis and interpretation. Bourne Press, Bournemouth

Davis AR, Targett NM, McConnell OJ, Young CM (1989) Epibiosis of marine algae and benthic invertebrates: natural products chemistry and other mechanisms inhibiting settlement and overgrowth. In: Suheuer PJ (ed) Bioorganic marine chemistry. Springer-Verlag, Berlin, p 85-114

Dexter SC, Sullicanm JD Jr, Williams J III, Watson SW (1975) Influence of substrate wettability on the attachment of marine bacteria to various surfaces. Appl Microb Ecol 30: 298-308

Dixon J, Schroeter SC, Kastendiek J (1981) Effects of the encrusting bryozoan, Membranipora membranacea, on the loss of blades and fronds by the giant kelp, Macrocystis pyrifera (Laminariales). J Phycol 17:341-345

Fletcher M, Marshall KC (1977) Are solid surfaces of ecological significance to aquatic bacteria? In: Marshall KC (ed) Advances in microbial ecology. Plenum Press, New York, p 199-236

Harder T, Lau SCK, Dobretsov S, Fang TK, Qian PY (2003) A distinctive epibiotic bacterial community on the soft coral Dendronephthya sp. and antibacterial activity of coral tissue extracts suggest a chemical mechanism against bacterial epibiosis. FEMS Microb Ecol 43:337-347

Henstchel U, Schmid M, Wagner M, Fieseler L, Gernert C, Hacker J (2001) Isolation and phylogenetic analysis of bacteria with antimicrobial activities from the Mediterranean sponges Aplysina aerophoba and Aplysina cavernicola. FEMS Microb Ecol 35:305-312

Holmström C, James S, Egan S, Kjelleberg S (1996) Inhibition of common fouling organisms by pigmented marine bacterial isolates. Biofouling 10:251-259

Jensen PR, Harvell CD, Wirtz K, Fenical W (1996) Antimicrobial activity of extracts of Garibbean gorgonian corals. Mar Biol 125:411-419

Kelman D, Kushmaro A, Loya Y, Kashman Y, Benayahu Y (1998) Antimicrobial activity of a Red Sea soft coral, Parerythropodium fulvum fulvum: reproductive and developmental considerations. Mar Ecol Prog Ser 169:87-95

Kubanek J, Whalen KE, Engel S, Kelly SR, Henkel TP, Fenical W, Pawlik JR (2002) Multiple defensive roles for triterpene glycosides from 2 Caribbean sponges. Oecologia 131: 125-136

Lau SCK, Mak KKW, Chen F, Qian PY (2002) Bioactivity of bacterial strains from marine biofilms in Hong Kong waters for the induction of larval settlement in the marine polychaete Hydroides elegans. Mar Ecol Prog Ser 226:301-310

Lee OO, Qian PY (2003) Chemical control of bacterial epibiosis and larval settlement of Hydroides elegans in the red sponge Mycale adhaerens. Biofouling 19(Suppl):171-180

Editorial responsibility: Dittmar Hahn,

Newark, New Jersey, USA
Lee S, Malone C, Kemp PF (1993) Use of multiple 16S rRNAtargeted fluorescent probes to increase signal strength and measure cellular RNA from natural planktonic bacteria. Mar Ecol Prog Ser 101:193-201

Lesser MP, Shumway SE, Cucci T, Smith J (1992) Impact of fouling organisms on mussel rope culture: interspecific competition for food among suspension-feeding invertebrates. J Exp Mar Biol Ecol 165:91-102

Liu WT, Marsh TL, Cheng K, Forney LJ (1997) Characterization of microbial diversity by determining terminal restriction fragment length polymophisms of genes encoding 16S rRNA. Appl Environ Microbiol 63:4516-4522

McCaffrey EJ, Endean R (1985) Antimicrobial activity of tropical and subtropical sponges. Mar Biol 89:1-8

Mitchell R, Chet I (1975) Bacterial attack of corals in polluted seawater. Microb Ecol 2:227-233

Nakanishi K, Nishijima M, Nomoto AM, Yamazali A, Saga N (1999) Requisite morphologic interaction for attachment between Ulva pertusa (Chlorophyta) and symbiotic bacteria. Mar Biotech 1:107-111

Paul VJ (1992) Chemical defenses of benthic marine invertebrates. In: Paul VJ (ed) Ecological roles of marine natural products. Comstock Publishing, Ithaca, NY, p 164-188

Penhale PA, Smith WO (1977) Excretion of dissolved organic carbon by eelgrass (Zostera marina) and its epiphytes. Limnol Oceanogr 22(3):400-407

Qian PY, Rittschof D, Sreedhar B (2000) Macrofouling in unidirectional flow: miniature pipes as experimental models for studying the interaction of flow and surface characteristics on the attachment of barnacle, bryozoan and polychaete larvae. Mar Ecol Prog Ser 207:109-121

Saitou N, Nei M (1987) The neighbor-joining method: a new method for reconstructing phylogenetic trees. Mol Biol Evol 4:406-425

Slattery M, McClintock JB, Heine JN (1995) Chemical defenses in Antaractic soft corals: evidence for antifouling compounds. J Exp Mar Biol Ecol 190:61-77

Targett NM, Bishop SS, McConnell OJ, Yoder JA (1983) Antifouling agents against the benthic marine diatom Navicula salinicola: Homarine from the gorgonian Leptogorgia virgulata and L. setacea and analogs. J Chem Ecol 9:817-829

Thakur NL, Anil AC (2000) Antibacterial activity of the sponge Ircinia ramose: importance of its surfaceassociated bacteria. J Chem Ecol 26:57-72

Thevanathan R, Nirmala M, Manoharan A, Gangadharan A, Rajarajan R, Dhamotharan R, Selvaraj S (2000) On the occurrence of nitrogen fixing bacteria as epibacterial flora of some marine green algae. Seaweed Res Utiliz 22: 189-197

Valsecchi E (1998) Tissue boiling: a short-cut in DNA extraction for large-scale population screenings. Mol Ecol 7: $1243-1245$

Wahl M (1989) Marine epibiosis. I. Fouling and antifouling: some basic aspects. Mar Ecol Prog Ser 58:175-189

Wahl M (1997) Living attached: aufwuchs, fouling, epibiosis. In: Nagabhushanam R, Thompson M (eds) Fouling organisms of the Indian Ocean: biology and control technology. Oxford and IBH Publishing Company, New Delhi, p 31-84

Wahl M, Jensen PR, Fenical W (1994) Chemical control of bacterial epibiosis on ascidians. Mar Ecol Prog Ser 110: $45-47$

Wieczorek SK, Todd CD (1998) Inhibition and facilitation of settlement of epifaunal marine invertebrate larvae by microbial biofilm cues. Biofouling 12:81-118

Witman JD, Suchanek TH (1984) Mussels in flow: dray and dislodgement by epizoans. Mar Ecol Prog Ser 110:45-47

Submitted: March 23, 2003; Accepted: October 1, 2003

Proofs received from author(s): December 22, 2003 